UDK 528.9

\title{
MAPPING THE UNDISCOVERED OBJECTS AND SITES IN LITHUANIA
}

\author{
Justinas Jasiūnas ${ }^{1}$, Edita Maneikaité丶 ${ }^{2}$, Paulius Venckus ${ }^{3}$, Denis Romanovas ${ }^{4}$, Giedrè Beconyte் ${ }^{5}$ \\ 1, ${ }^{4}$ Vilnius Gediminas Technical University, Sauletekio al. 11, 10223 Vilnius, Lithuania \\ 2, 3, 5 Vilnius University, Universiteto g. 3, 01513 Vilnius, Lithuania \\ E-mails: 1j.jasiunas@gis-centras.lt (correspondingauthor); ${ }^{2}$ edita.maneikaite@gmail.com; \\ ${ }^{3}$ venckus.pauliaus@gmail.com; ${ }^{4}$ denis.romanovas@gmail.com; ${ }^{5}$ giedre.beconyte@gf.vu.lt
}

Received 23 April 2013; accepted 16 May 2013

\begin{abstract}
Forlorn, uncared-for cultural or natural objects and sites fail to be included into lists of touristic attractions due to their obscurity, poor condition and communication and are usually visited by certain social groups (extreme adventure travellers, members of various subcultures and etc.). The analysis revealed a wide array of such objects and sites, which are unknown and not in very good condition, can be very different starting with manor houses, historic parks and gardens and finishing with airfields, open courses or dumping grounds. The goal of a pilot research project carried out at the National Centre of Remote Sensing and Geoinformatics "GIS-Centras" was to collect information on diverse objects and sites that are typically not included into official information sources and fall outside the tourist infrastructure network. The collected information will be published as a map service. The inventory of such undiscovered objects and sites and visualisation is one of the ways to encourage the interest of visitors, especially in regions that lack famous tourist attraction objects or beautiful landscapes. The paper describes solutions for the structure of the database, object acquisition technology, cartographic visualisation and publication of collected data as an online map at www.nemasinis.lt...
\end{abstract}

Keywords: alternative tourism, undiscovered object, abandoned site, map, inventory.

Reference to this paper should be made as follows: Jasiūnas, J.; Maneikaite, E.; Venckus, P.; Romanovas, D.; Beconyte, G. 2013. Mapping the undiscovered objects and sites in Lithuania, Geodesy and Cartography 39(2): $64-71$.

\section{Introduction}

Political and subsequent economic reforms, which started twenty years ago, essentially changed the structure of the society, the form of ownership, economic relations and the farming system. Consequently, the territory of Lithuania was studded in thousands of structures that were abandoned after their initial purpose was lost. Usually, these objects were inappropriately maintained and were considered unfit for some new purpose. That happened to many former agricultural, militaristic, commercial or residential objects, graveyards, airfields and other objects and sites (Apleistų... 2008).

Authenticity and "intact" historical heritage of these objects and locations attracts various different social groups, such as extreme adventure travellers, members of various subcultures and etc. Some of these objects and sites have a potential to become offici- al sites for historic, cognitive, extreme or some other type of tourism. An inventory database of such objects could serve not only for diverse subcultures, that enjoy exploring abandoned or undiscovered sites and objects, but also for tour organisers, hikers or other unusual activities. Inventory of uncommonly visited objects and sites, efficient recording of information and visualisation is one of the ways to encourage the interest of visitors, especially in regions that lack popular official tourist attractions.

The project of the programme Crowd Sourcing in National Mapping was carried out with a goal to collect and visualise such potential tourism objects and sites in Lithuania. The project focused on collecting information on objects without any tourism infrastructure that typically fall outside official information sources; however, they are potentially interesting or 
valuable to particular groups of the society (mainly young people). Examples of such objects are abandoned fortifications, caverns, sites of extinct villages, esoteric sites and etc. (Fig. 1).

First of all, the current situation of undiscovered objects and sites in Lithuania was analysed and a new definition of an undiscovered object and site was formulated. Then, methodology for database organisation and visualisation of collected information was developed.

\section{Analysis of the current situation}

Specific sources, covering objects and sites as they were defined, are very sparse. Most of the existing sources describe abandoned objects and locations in Lithuania and abroad. Therefore, the current situation analysis is based on websites related to urban exploration, digging, historical research and etc.

The analysis focused on major Lithuanian websites, which provide some information about undiscovered objects and sites. These websites were analysed

a)

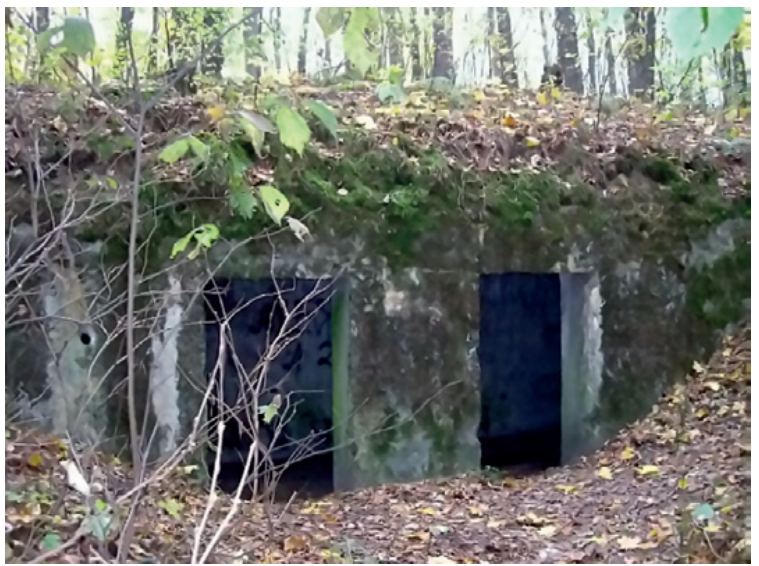

b)

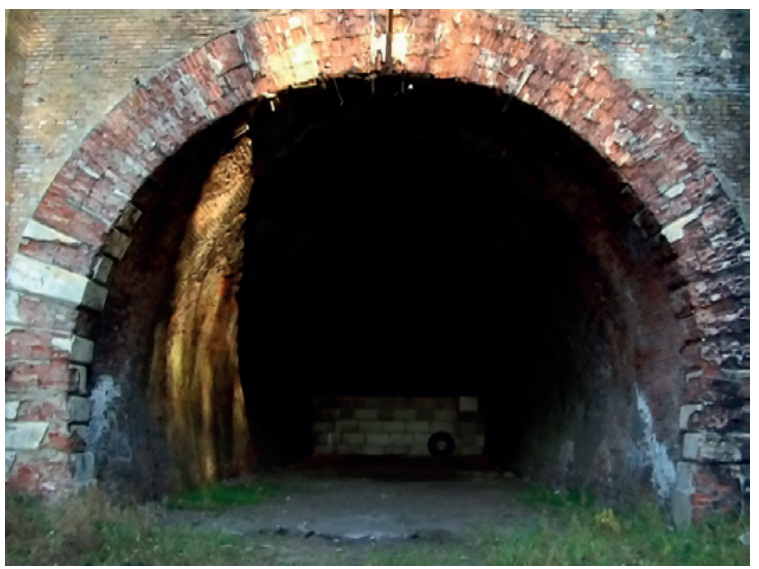

Fig. 1. Examples of potential tourism objects in Vilnius: a) artillery fortifications in Belmontas; b) the Paneriai tunnel (http://vilniusguide.wordpress.com) by classification of objects and sites, the publicity of their accurate coordinate, visualisation, possibility to sort and etc. Only some websites provide the classification of objects and sites. It is important to mention that usually the existing classifications of objects lack a clear classification criterion. The exceptions are www. digeriai.lt and www.pamirsta.lt, which have two classification criteria: appearance and topic or purpose.

Aiming to ensure the safety of visitors, prevent destruction and acts of vandalism, no accurate coordinates of objects are provided on the aforementioned websites. However, www.urbanexploration.lt offers an interactive map, which provides the possibility to determine the position of an object. This map enables a user to analyse the distribution of undiscovered objects and sites in Lithuania.

Photographs are the key form of visual information that supplements textual information on all websites. One of the websites also provides some video recordings.

On www.digeriai.lt and www.antraspasaulinis.net, registered users are free to comment or upload information. Other websites do not have this functionality as data can only be edited by website administrators.

The analysis revealed advantages and disadvantages of such websites, which was useful for the development of an improved website of the type.

Because of the variety of undiscovered objects and sites listed in these websites and other information sources, it was necessary to clearly define such attractions. Primarily, the idea of alternative tourism attractions was suggested as such objects and sites are not attributable to the mass or conventional tourism. The concept is not precise as alternative tourism is a broad category, which includes different types of tourism from the oldest to newest forms that all have a single common characteristic, namely, is an alternative to mass tourism (Novelli 2005). Usually, such forms of tourism are associated with small groups of explorers, usually educated, with specific interests (Kinderis 2010). Main forms of alternative tourism are: cultural tourism, social tourism, ecotourism, rural tourism, medical tourism and urban tourism (Wearing, Neil 1999). Usually, alternative tourism is defined as a process that seeks to achieve mutual understanding, solidarity and equality amongst participants (Holden 1984). Or it is a type of tourism that is ecologically sound and avoids the negative impacts of many large scale tourism developments (Lertcharoenchoke 1999). In Lithuania, alternative tourism is understood as a type of tourism with a purpose to reduce a negative 
impact and to increase a positive impact on social, cultural and physical environment. It creates an alternative to the mass tourism and is associated with protection of nature and nurturance of national customs and traditions (Aiškinamasis... 2009).

The objects and sites analysed by the authors partially fall into the area of alternative tourism. They attract certain groups of visitors and they have potential to be organized by particular communities. They are different and may be used for various forms of alternative tourism. However, in many cases these objects and sites fail to correspond to the idea of ecofriendly tourism because of pollution or hazardousness. For example, urban explorers can be interested in an old chemical factory yet it may contain environmentally hazardous substances harmful to human health. Some derelict objects can cause accidents. The authors propose an original definition: undiscovered tourist objects and sites are cultural or natural objects and sites that fail to be included into lists of mass tourism attractions due to their obscurity, poor condition and communication and are sporadically or regularly visited by certain social groups (extreme adventure travellers, members of various subcultures and etc.). This definition fits a large number of different objects and sites that have a fair potential to attract tourists to their region.

\section{Methodology}

\subsection{Data and object classification}

As it was stated before, undiscovered objects and sites exist in a great variety. This makes classification of such objects and sites somewhat complex. Data attributes pertaining to objects and sites are divided into types and subtypes, classified according to their condition, impact on the environment or visitors.

Firstly, all objects and sites are divided into two basic types:

- Natural objects and sites (trees, scarps, sinkholes and etc.);

- Cultural objects and sites (buildings, monuments and etc.).

Each of these basic types can be divided into subtypes. The importance of subtypes is to clarify the types, because they combine too many different objects and sites. Only one unique criterion - appearance - was selected to avoid vagueness. A discussion was held on the criterion to be selected and the main candidates were appearance or topic. The later was finally rejected as the variety of possible topics is too wide, thus, it would be difficult to make a complete classification. Meanwhile, appearance as the criterion limits the number of possible subtypes to the certain number as all similar objects are combined into one subtype. For instance, a bridge, viaduct and other similar structures are attributed to the same subtype.

As the majority of objects are attributed to the cultural type, the subtypes and subsequent classifications are not provided for natural objects.

According to their condition, cultural objects are also classified into the following groups:

- Functional - objects that maintained their primary purpose;

- Abandoned - neglected and nonfunctional objects;

- Closed - maintained but nonfunctional objects;

- Demolished - ruined objects;

- Rebuilt - objects that did not necessarily maintain their primary purpose;

- Protected - functional or nonfunctional objects that are protected by state institutions.

Some objects and sites may have an environmental impact or pose a health and safety risk for visitors. Environmental impact is determined assessing a possible chemical and physical (vibration, radiation, noise and etc.) pollution. Health and safety risks for visitors are determined assessing the condition of the object (rebuilt, tumbledown).

The following groups have been made in order to evaluate possible environmental impact:

1. Safe objects;

2. Moderately hazardous objects;

3. Very hazardous objects.

Analogous groups were made to grade possible health and safety risks for visitors.

\subsection{Cartographic symbols}

Undiscovered objects and sites are points and as their subtypes are qualitative, they can be represented by point symbols (Asche, Hermann 2002). In mapping categorical data, cartographers often focus on displaying different categories, types, subtypes or classes through shape or colour hue. Also, different categories can be visualised through different associative signs, which keep the direct similarity link with a pictorial object or site. Associative symbols have been designed for each subtype of the cultural type (Fig. 2).

The colour of associative symbols is also important because it can help attributing a certain feel to an object. For example, grey colour represents neutrality 


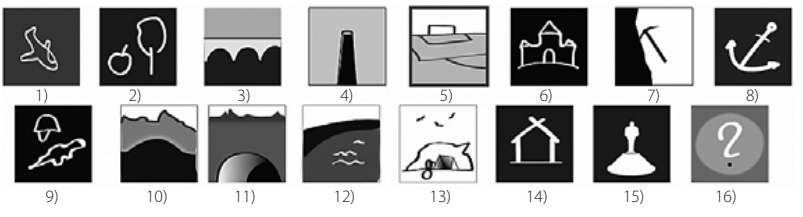

Fig. 2. Conventional symbols for the cultural type of undiscovered objects and sites: 1) aerodromes; 2) gardens, parks; 3) bridges; 4) tall structures; 5) stadiums; 6) fortresses and fortifications; 7) quarries, mines; 8) ports and harbours; 9) ilitary training grounds and bases; 10) cemeteries, barrows; 11) underground structures; 12) dams; 13) dumping grounds; 14) buildings; 15) monuments; 16) others

or rest and thus can be used to visualise a more negative phenomenon or object. Usually perceived as neutral, grey colour is used to mark undiscovered objects and sites.

\subsection{Database design and organisation}

The data set is designed for three different types of users:

1. Anonymous users. They can view all provided data and make data queries;

2. Registered users. Any registered and logged-in user can do limited editing tasks: enter, edit, and delete existing data. This data access is essential for the development of the project, as almost all of the data will be entered by this type of users;

3. Administrator is responsible for the correction of entered data of registered users. Some data is published on the website only after administrator's review and evaluation.

Database building consists of two stages: mapping and entering attribute information. First of all, an object or site is marked on the interactive map of Lithuania. Then, attribute data is entered into the table that appears on the screen. There are some restrictions for each field of this table (Table 1).

All objects and sites are registered as points in the Lithuanian Coordinate System 1994 (LKS 94) on the interactive map. The map is based on the spatial data set of reference base of the territory of Lithuania. The copyright holder of this dataset is the National Land Service under the Ministry of Agriculture of the Republic of Lithuania. The names of databases are GDR10LT (georeferential spatial data set M 1:10 000 of the Republic of Lithuania), GDR250LT (georeferential spatial data set M 1:250 000 of the territory of the Republic of Lithuania), ORT10LT (digital raster ortophoto map M 1:10 000 of the Republic of Lithuania (2009-2010)). A point can be marked directly on the
Table 1. Table of attribute data

\begin{tabular}{|c|c|c|c|}
\hline Field name & $\begin{array}{c}\text { Input } \\
\text { data type }\end{array}$ & Compulsory? & $\begin{array}{c}\text { Drop- } \\
\text { down list? }\end{array}$ \\
\hline Name & Text & Yes & No \\
\hline Type & Text & Yes & Yes \\
\hline Subtype & Text & Yes & Yes \\
\hline Primary purpose & Text & No & No \\
\hline Age & Text & No & No \\
\hline Condition & Text & No & Yes \\
\hline $\begin{array}{c}\text { Hazardousness for } \\
\text { the environment }\end{array}$ & Text & No & Yes \\
\hline $\begin{array}{c}\text { Hazardousness for } \\
\text { the visitors }\end{array}$ & Text & No & Yes \\
\hline $\begin{array}{c}\text { General } \\
\text { information }\end{array}$ & Text & No & No \\
\hline Photo & File & No & No \\
\hline Video & File & No & No \\
\hline
\end{tabular}

map or entered as coordinates (latitude and longitude) of the object or site. After marking of objects and sites, the table of attribute data automatically appears on the screen (Fig. 3).

All users can comment on each registered object or site. The link between users, comments and objects tables of database is presented in the Fig. 4.

Attribute data set consists of 5 compulsory and 6 optional fields. The main attribute date fields can be divided into two groups: identification (name, type, subtype) and security (hazardousness for the environment and visitors). Other fields detail additional information about the untrodden object or site. All of methodological aspects of input of attributes data were represented in the Fig. 5.

\section{Web map application}

\subsection{The technology of web map application}

There are quite a few technologies for making of a web map application. Some of them are plug-in-based RIA (rich internet application) technologies such as Adobe Flash, Adobe Flex or Microsoft Silverlight. They have a number of advantages, such as fast graphic rendering, but they are not web browser native. It means that web users must have that technology plug-in installed into their computer in order to view a web map application. Another approach is to use web browser native technologies such as HTML, CSS, JavaScript and SVG. The main advantage of this approach is that all current web browsers support its technologies, including mobile web browsers. 


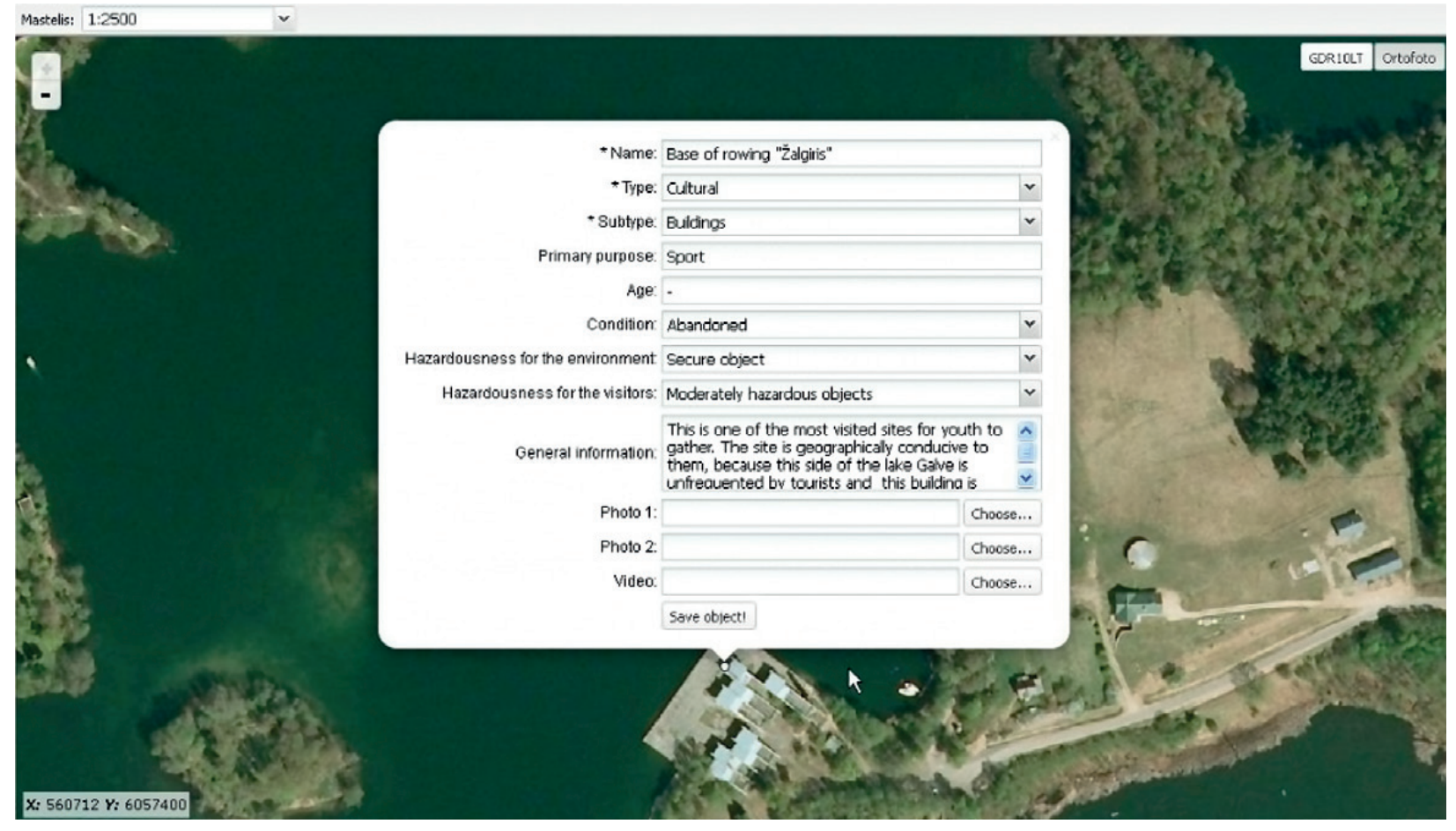

Fig. 3. User interface for entering an object or site on the interactive map. For example, the rowing club Žalgiris in Trakai

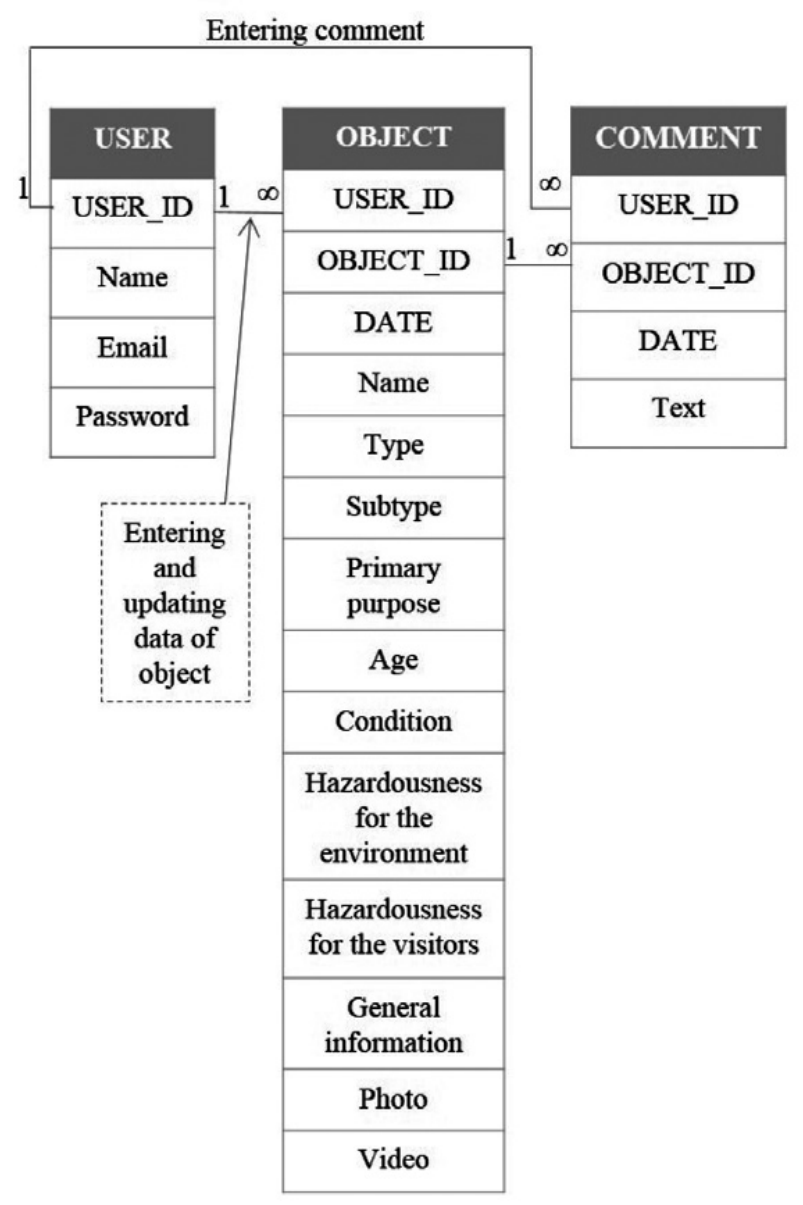

Fig. 4. Database structure in tables
Web mapping application at http://www.nemasinis.lt/ (Application in future references) was created using that one last approach, which doesn't force a user to mess with computer plug-ins.

As there are many open source JavaScript web mapping APIs (e.g. OpenLayers, Leaflet, Modest Maps) these days, there is no need to invent one in order to create a web app.

All web mapping APIs have their advantages and drawbacks, but Leaflet seemed to be the best choice as it is lightweight, usable and easily customisable, so Application mapping functionality was created using Leaflet. Although it was somewhat challenging to make Leaflet, which uses EPSG:3857 coordinate system, and work with ArcGIS server REST services that use EPSG:3346 coordinate system, the problem was successfully resolved. As graphics geometry of the Application is simple (all graphics are points), there was no need to create a spatial database and a plain $M y S Q L$ database table was used instead. Application web services like "points geometry query" or "point of interest creation query" were created using PHP programming language.

The main reason to choose PHP as a server - side programming language was Lithuanian, shared hosting services support this programming language - all popular Lithuanian shared hosting services don't offer 


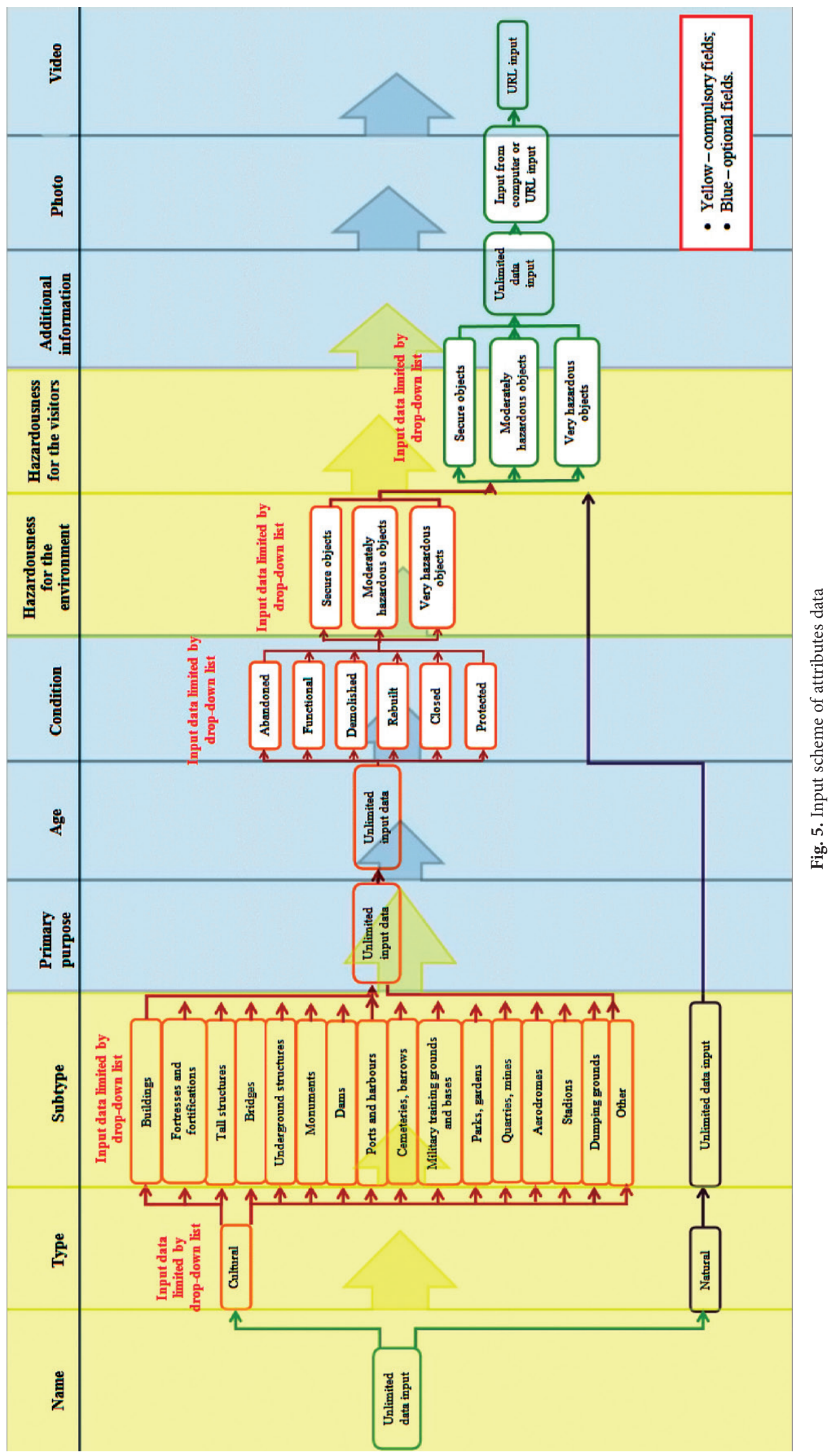


other programming languages than PHP. Application user interface widgets were created using powerful $\mathrm{Ja}$ vaScript Framework ExtJS 4.

\subsection{Management of data volume entered online}

It is difficult to estimate the real number of undiscovered objects and sites that will be entered by users of the Application, but the authors believe it could reach a couple of thousand at best. This number is not large in terms of data sent from a server to a client. Thus, during development of the web map application, great efforts were invested to reduce the server load and perform the largest possible portion of data processing on the side of a client. The main concern is rendering vector graphics on the client side. Currently SVG technology is used to render vector data on undiscovered objects and all vector graphics are rendered. Experiments carried out during development showed that App map pan and zoom slows down noticeably when the number of objects approaches 500. There are two possible ways to fix the problem:

1) Cluster vector graphics for small map scales.

2) Use of HTML5 Canvas API instead of SVG for vector graphics.

These two methods are still under investigation and heave not yet been implemented. The authors seek to implement one of the methods before a critical number of graphic objects is reached.

\subsection{Search functionality}

The App offers a search of undiscovered objects based on the object title. A search is made on the client side. First of all, a search keyword is lowercased and normalised (e.g. a letter "s" is converted into "s"). Then, the loop through lowercased and normalised titles of all undiscovered objects is executed. For every iteration of an item in the loop, JavaScript's substr() method is used, which determines if an item contains the search keyword.

All successful matches are displayed to the user. This search method acts like a SQL's "LIKE" query. With small datasets, this data search algorithm returns results almost instantly; however, a search may take a second or so in case of datasets with a couple of thousand records, which means that the web browser would freeze for a second or so. This situation could be fixed using a server side database and SQL queries, using HTML5 Web Workers API or just simply displaying first 25 (50 or 100) matches.

\section{Acknowledgement}

The paper was prepared as a part of the project Crowd Sourcing in National Mapping (2012-2013) co-funded by the AGILE and EuroSDR.

\section{Conclusions}

1. The database and application of undiscovered objects and sites are original in several aspects:

a) Classification of objects and sites by appearance;

b) Unique cartographic symbols specifically designed for each subtype of objects and sites;

c) Possibility to analyse the collected data by municipalities and by subtypes;

d) Possibility to view collected data as online map at www.nemasinis.lt; to enter and edit data online using the Web application designed and developed by the authors.

2. Inventory of undiscovered objects and sites and visualisation is one of the ways to stimulate visitor interest, especially in regions that lack famous official objects or beautiful landscapes.

3. Potential objects or sites for alternative tourism must be analysed in order to model and to legalise alternative tourism that could become an attractive branch of tourism in Lithuania. A significant part of unknown or abandoned objects has a potential to be developed into official sites of historical, extreme or other type of tourism. Some of them may be dangerous or unwanted (such as some graffiti) and corresponding actions can be taken when the inventory database and a map with spatial analysis models are available. Availability of aggregated information on a public map with route planning tools would encourage visitor interest, especially in regions that lack famous tourist attractions.

\section{References}

Aiškinamasis turizmo terminu žodynas. 2009 [online], [cited on 10 March 2013]. Vilnius, Valstybinis turizmo departamentas prie Lietuvos Respublikos ūkio ministerijos, Mokslo ir enciplopedijų leidybos institutas. Available on the Internet: http://www.tourism.lt/upload/Turizmo_zod.pdf

Antrasis pasaulinis karas. Source of untrodden objects and sites in Lithuania [online], [cited on 10 March 2013]. Available on the Internet: www.antraspasaulinis.net

Apleisti.lt.: apleisti ir iš naujo atrasti. Source of untrodden objects and sites in Lithuania [online], [cited on 4 March 2013]. Available on the Internet: www.apleisti.lt 
Apleistu statiniu likvidavimo programa. 2008. Parengè UAB Hnit-Baltic ir UAB Statybos projektų ekspertizès centras. $159 \mathrm{p}$.

Asche, H.; Hermann, C. 2002. Thematic cartography, in R. W. Anson and F. J. Ormeling (Eds.). Basic Cartography for students and technicians. Vol. 2. UK, Oxford: Butterworth Heinemann, 123-150.

Holden, P. 1984. Alternative Tourism: Report on the Workshop on Alternative Tourism with a Focus on Asia. Ecumenical Coalition on Third World Tourism. Bangkok.

Kinderis, R. 2010. Socialinio turizmo, kaip alternatyvios turizmo formos, adaptacija Europoje, Profesinés studijos: teorija ir praktika 2010/6: 99-106.

Lertcharoenchoke, N. 1999. Alternative tourism, ABAC Journal 19(2) [online], [cited on 1 March 2013]. Available on the Internet: http://www.journal.au.edu/abac_journal/may99/ article4_f.html

Lietuvos digeriai. Source of historical untrodden objects and sites in Lithuania [online], [cited on 10 March 2013]. Available on the Internet: www.digeriai.lt

Nieko naujo. Source of historical untrodden objects and sites in Lithuania [online], [cited on 8 March 2013]. Available on the Internet: www.niekonaujo.lt

Novelli, M. 2005. Niche Tourism: Contemporary Issues, Trends and Cases. UK, Oxford: Butterworth Heinemann, 247-251. http://dx.doi.org/10.1016/B978-0-7506-6133-1.50031-7

Pamiršta.lt. Source of untrodden objects and sites in Lithuania [online], [cited on 8 March 2013]. Available on the Internet: www.pamirsta.lt

Urbanexploration.lt: miesto tyrinejimas Lietuvoje. Information about urban exploration in Lithuania [online], [cited on 10 March 2013]. Available on the Internet: www.urbanexploration.lt

Wearing, S.; Neil, J. 1999. Ecotourism: Impacts, Potentials and Possibilities. UK, Oxford: Butterworth Heinemann, 3-4.
Justinas JASIŪNAS. Student of Geodesy and Cartography, Master's Degree programme, Vilnius Gediminas Technical University, Saulètekio al. 11, LT-10223 Vilnius, Lithuania. Bachelor's Degree in Geodesy, 2012, Vilnius Gediminas Technical University.

Research interests: open source in geographic information systems.

Edita MANEIKAITE். Student of Cartography, Master's Degree programme, Vilnius University, Universiteto g. 3, LT-01513 Vilnius, Lithuania. Bachelor's Degree in Ecology, 2011, Vilnius University.

Research interests: use of geographic information systems (GIS) in ecology and biology.

Paulius VENCKUS. Student of Cartography, Master's Degree programme, Vilnius University, Universiteto g. 3, LT-01513 Vilnius, Lithuania. Bachelor's Degree in Geography, 2011, Vilnius University.

Research interests: stylistic features of the XVI-XIX century maps, cultural geography.

Denis ROMANOVAS is MSc student at Vilnius Gediminas Technical University and GIS programmer at the State Enterprise "GIS-Centras". His research interests include GIS analysis and application programming.

Giedrè BECONYTÉ is Professor at the Centre for Cartography, Vilnius University. She has published more than 40 papers in scientific journals as well as conference proceedings and textbooks on spatial analysis and DBMS. Her current research interests include thematic mapping, geographic information system design and project management. 